\title{
TERAPI NUTRISI PADA NEFROPATI DIABETIK, GAGAL JANTUNG KRONIK NYHA III, KARSINOMA SERVIKS, POST OPERASI URS BILATERAL, REPLACE DJ STENT
}

\author{
Andi Syurma Sari Ismail ${ }^{1}$, Agussalim Bukhari ${ }^{2}$ \\ ${ }^{I}$ Residen Ilmu Gizi Klinik, Universitas Hasanuddin, Makassar, \\ e-mail:andi_syurmasari@yahoo.com \\ ${ }^{2}$ Departemen Ilmu Gizi, Universitas Hasanuddin, Makassar, \\ e-mail :agussalimbukhari@yahoo.com
}

\begin{abstract}
Abstrak
Nefropati Diabetik atau Diabetic Kidney Disease (DKD) adalah perubahan struktural dan fungsional patologis spesifik yang terlihat pada ginjal pasien Diabetes Mellitus (DM). Nefropati diabetik menyebabkan berbagai perubahan pada kapiler dan arteri, penebalan membran endotel, trombosis dan inflamasi. Kondisi ini terlihat setelah satu atau dua tahun menderita DM. Diabetes mellitus juga dapat berkontribusi pada gagal jantung kronik dengan mekanisme sistemik, miokard, dan seluler. Semua faktor inilah yang dapat menyebakan malnutrisi. Ini adalah laporan kasus dari seorang wanita berusia 50 tahun, dengan keluhan tidak ada asupan oral sejak 1 hari yang lalu, didiagnosis dengan moderate protein energy malnutrition (Subjective Global Assessment score B), nefropati diabetik, gagal jantung kronik NYHA III dengan karsinoma serviks dan pasca operasi URS Bilateral, Replace DJ Stent. Terapi nutrisi diberikan $720 \mathrm{kkal}$, ditingkatkan bertahap menjadi $2000 \mathrm{kkal}$ sesuai kemampuan dan kondisi pasien, dengan komposisi 0,8-1 g / kg BB ideal / hari protein dan ekstrak ikan gabus, 45-50\% karbohidrat dan 41-47\% lemak diikuti dengan suplementasi zink (20 mg / hari), vitamin B kompleks, dan kurkumin. Terjadi peningkatan asupan energi dari $245 \mathrm{kkal}$ menjadi 2.142,6 kkal diikuti dengan peningkatan hasil laboratorium seperti penurunan ureum / kreatinin (114 / 3,2 menjadi 84 / 2,05 mg / dl, penurunan leukosit (14.000 menjadi $7200 / \mu \mathrm{l})$, penurunan asam urat $(13,1$ hingga 7,3$) \mathrm{mg} / \mathrm{dl}$, penurunan kadar gula darah (199 menjadi $162 \mathrm{~g} / \mathrm{dl}$ ), peningkatan hemoglobin (6,7 hingga 8,2 g / dl), peningkatan kadar natrium (128 hingga $131 \mathrm{mmol} / \mathrm{l})$ Kesimpulan: Pemberian terapi gizi yang adekuat selama 16 hari perawatan dapat memperbaiki kondisi, status metabolisme dan kualitas hidup pasien.
\end{abstract}

Kata kunci : nefropati diabetik, malnutrisi, inflamasi, diabetes mellitus.

\begin{abstract}
Abstrak
Diabetic Nephropathy (DN) or Diabetic Kidney Disease (DKD) is a specific pathological structural and functional change seen in the kidneys of Diabetes Mellitus (DM). Diabetic nephropathy causes various changes in the capillaries and arteries, thickening of the endothelial membrane, thrombosis and inflammation. This condition can be seen after one or two years of DM. Diabetes mellitus can also contribute to chronic heart failure with systemic, myocardial and cellular mechanisms. All of this factors can cause malnutrition. This is a case report of a 50 year old woman, with complaints no oral intake since 1 day ago, diagnosed with moderate protein energy malnutrition (Subjective Global Assessment score B), nephropathy diabetic, chronic heart failure NYHA III with carcinoma cervix and post operation URS Bilateral, Replace DJ Stent. Nutritional therapy is given $720 \mathrm{kcal}$, gradually increased to $2000 \mathrm{kcal}$ according to the patient's ability and condition, with a composition of $0.8-1 \mathrm{~g} / \mathrm{kg}$ ideal $\mathrm{BW} /$ day protein and snakehead fish extract, $45-50 \%$ carbohydrate and $41-47 \%$ fat followed by supplementation of zinc (20 mg / day), vitamin B complex, and curcumin. We found an increase in energy intake from $245 \mathrm{kcal}$ to 2142.6 kcal was followed by improvement of laboratory results such as decreased ureum/creatinine $(114 / 3.2$ to $84 / 2.05 \mathrm{mg} / \mathrm{dl}$, decreased leukocytes (14.000 to $7200 / \mu \mathrm{l})$, decreased uric acid $(13.1$ to 7.3$) \mathrm{mg} / \mathrm{dl}$, decreased blood sugar levels (199 to $162 \mathrm{~g} / \mathrm{dl}$ ), increased haemoglobin (6.7 to 8.2
\end{abstract}


$\mathrm{g} / \mathrm{dl}$ ), increased sodium levels (128 to $131 \mathrm{mmol} / \mathrm{l})$. Conclusion : Adequate nutritional therapy for 16 days can improve the condition, metabolic status, and quality of life patients.

Keywords : diabetic nephropathy, malnutrition, inflammation, diabetes mellitus

\section{Pendahuluan}

Nefropati Diabetik (ND) atau Diabetic Kidney Disease (DKD) merupakan komplikasi utama dari Diabetes Mellitus (DM). Diagnosis mengacu pada perubahan struktural dan fungsional patologis spesifik yang terlihat pada ginjal pasien DM, baik tipe 1 dan tipe 2 yang dihasilkan dari efek DM pada ginjal. Perubahan ini menghasilkan gejala klinis yang ditandai dengan proteinuria, hipertensi, dan penurunan fungsi ginjal secara progresif. Nefropati diabetik adalah penyebab utama penyakit ginjal tahap akhir di Amerika Serikat dan sebagian besar negara maju. Diabetes mellitus menyumbang 30\% hingga $50 \%$ dari insiden penyakit ginjal tahap akhir di Amerika Serikat. Meskipun merupakan masalah kesehatan masyarakat yang signifikan, penting untuk dicatat bahwa hanya $30 \%$ hingga $40 \%$ pasien DM yang mengalami nefropati diabetik. (1), (2)

Nefropati diabetik dikaitkan dengan morbiditas dan mortalitas kardiovaskular yang lebih tinggi, sehingga diagnosis dan perawatan yang tepat waktu sangat penting. Secara global, lebih dari 400 juta orang menderita diabetes mellitus dan hampir 600 juta orang mungkin terkena dampaknya pada tahun 2035. Di Amerika Serikat, sekitar $12 \%$ populasi menderita diabetes, dan hingga $25 \%$ dari orang-orang ini mungkin tidak terdiagnosis. Berdasarkan data Riskesdas tahun 2018, prevalensi DM secara nasional meningkat bila dibandingkan dengan data pada tahun 2013, yaitu dari 6,9\% menjadi 8,5\%.(3) Penyakit ini mempengaruhi pasien di semua kelompok umur, jenis kelamin, ras atau kelompok etnis, tingkat pendidikan, dan tingkat pendapatan. (1)

Faktor risiko utama penyebab ND adalah hiperglikemia, hipertensi arteri, faktor genetik pada DM tipe 1 dan 2. Faktor risiko lainnya adalah merokok, dislipidemia, proteinuria, hiperfiltrasi glomerulus, dan faktor makanan. (4)

Diabetes mellitus juga merupakan prediktor penting dari perkembangan gagal jantung simptomatik pada pasien dengan asimptomatik disfungsi sistolik ventrikel kiri. Selanjutnya, kontrol glikemik yang buruk dikaitkan dengan risiko lebih besar untuk perkembangan gagal jantung, dimana setiap $1 \%$ peningkatan hemoglobin A1c (HbA1c), risiko insiden gagal jantung meningkat sebesar $8 \%$ menjadi $36 \%$. Risiko insiden gagal jantung diantara pasien dengan 
DM meningkat dengan usia yang lebih tua.(5),(6)

Malnutrisi pada nefropati diabetik diakibatkan oleh penurunan asupan. Malnutrisi pada ND tidak sepenuhnya dapat dijelaskan dengan berkurangnya asupan nutrisi. Interaksi yang rumit dari berbagai faktor, termasuk ketidakseimbangan hormon, penurunan nafsu makan dan asupan makanan, inflamasi, peningkatan katabolisme, dan gangguan metabolisme mempengaruhi pasien ND menjadi malnutrisi. Berikut adalah laporan kasus dengan pasien ND disertai gagal jantung kronik NYHA III, karsinoma serviks, post replace DJ stent. Terapi nutrisi pada pasien ini ditujukan untuk mencegah / memperlambat perburukan klinis dari kondisi pasien.(4)

\section{Laporan Kasus}

Ny. Y, seorang ibu rumah tangga, berusia 50 tahun, dikonsultasikan dari Departemen Bedah Urologi dengan diagnosis ND disertai gagal jantung NYHA III, karsinoma serviks, post replace DJ stent. Laporan kasus ini dibuat setelah mendapatkan persetujuan pasien secara lisan.

Pasien masuk rumah sakit karena merasa lemas dan pucat. Riwayat kesadaran menurun sejak 1 hari yang lalu. Terdapat sesak napas sejak 1 hari yang lalu. Riwayat DM diketahui sejak lebih kurang 5 tahun yang lalu, berobat tidak teratur dengan pemakaian insulin hanya 1 bulan pada bulan September 2017. Terdiagnosis karsinoma serviks 1,5 tahun yang lalu, sudah menjalani kemoterapi 6 siklus dan radioterapi sebanyak 55 kali. Terdiagnosis hidronefrosis bilateral 5 bulan yang lalu. Penurunan berat badan ada sejak 1,5 tahun yang lalu, besar penurunan berat badan tidak diketahui secara pasti.

Pada pemeriksaan fisik tampak lemah, sakit sedang dengan tekanan darah 100/70 mmHg, frekuensi nadi $78 \mathrm{kali} / \mathrm{menit}$, frekuensi napas $28 \mathrm{kali} / \mathrm{menit}$, Saturasi oksigen $99 \%$ dengan modalitas non rebreathing mask oksigen 15 liter/menit. Antropometri : tinggi badan $155 \mathrm{~cm}$, lingkar lengan atas $28 \mathrm{~cm}$, berat badan ideal $49,5 \mathrm{~kg}$ dan berat badan prediksi berdasarkan lingkar lengan atas $53,9 \mathrm{~kg}$. Terdapat edema pada kedua dorsum pedis dan pretibial, tanpa ada kehilangan jaringan lemak subkutan dan muscle wasting. Pemeriksaan laboratorium ditemukan hemoglobin $6,7 \mathrm{~g} / \mathrm{dL}$, white blood cell (WBC) $14.000 / \mathrm{ml}$, total lymphocyte count (TLC) $924 / \mu \mathrm{L}$, trombosit $130.000 / \mathrm{mm}^{3}$, ureum $144 \mathrm{mg} / \mathrm{dL}$, kreatinin $3.2 \mathrm{mg} / \mathrm{dL}$, natrium $128 \mathrm{mmol} / \mathrm{L}$, kalium 4.3 $\mathrm{mmol} / \mathrm{L}$ dan albumin $2.8 \mathrm{~g} / \mathrm{dL}$, protein total 
5,2 gr, gula darah sewaktu (GDS) 398 $\mathrm{mg} / \mathrm{dl}$, asam urat $13,1 \mathrm{mg} / \mathrm{dL}$.

Status gizi moderate protein energy malnutrition berdasarkan subjective global assessment (SGA). Terapi nutrisi pada awalnya diberikan 950 kkal dinaikkan secara bertahap sesuai kondisi gejala klinis dan hasil pemeriksaan laboratorium sampai dengan target energi 2000 kkal (100\% kebutuhan energi) pada hari ke-14 sampai pasien pulang. Komposisi makronutrien : karbohidrat $45-50 \%$, protein $0,8-1$ $\mathrm{gr} / \mathrm{kgBBI} / \mathrm{hari}$ dan lemak $41-47 \%$ awalnya berupa blenderized food, oral nutritional supplementation (ONS) rendah protein dan mono unsaturated fatty acid (MUFA) kemudian ditingkatkan secara bertahap dengan preskripsi makanan lunak, kombinasi ONS rendah protein dan mono unsaturated fat (MUFA), dan buah. Suplementasi mikronutrien : zink $20 \mathrm{mg} / 24$ jam, curcuma $400 \mathrm{mg} / 8$ jam, vitamin B kompleks 2 tablet/ 8 jam, vitamin C 100 $\mathrm{mg} / 12 \mathrm{jam}$, vitamin A $6000 \mathrm{IU} / 24 \mathrm{jam}$ dan ekstrak ikan gabus 2 kapsul/ 8 jam.

Saat dipulangkan terdapat perbaikan klinis, berupa pasien dalam keadaan sadar dan sudah dapat duduk dikursi secara mandiri, tidak sesak napas, peningkatan asupan oral dengan rata-rata selama 16 hari perawatan $83-100 \%$ kebutuhan energi, dan perbaikan dalam fungsi ginjal dengan (ureum $84 \mathrm{mg} / \mathrm{dL}$, kreatinin $2.05 \mathrm{mg} / \mathrm{dL}$ ), hemoglobin 8,2 g/dl, WBC $7.600 / \mathrm{ml}$, trombosit $223.000 \quad / \mathrm{mm}^{3}$, perbaikan elektrolit (natrium $131 \mathrm{mmol} / \mathrm{L}$ dan kalium $4,4 \mathrm{mmol} / \mathrm{L}$ ), protein total $6,3 \mathrm{gr} / \mathrm{dL}$, asam urat $7,3 \mathrm{mg} / \mathrm{dL}$. Namun terdapat penurunan pada TLC menjadi 554,8 /ml.

\section{Pembahasan}

Malnutrisi pada pasien dengan gagal jantung kronik dikaitkan dengan adanya penurunan asupan karena adanya kesadaran menurun, peningkatan kebutuhan nutrisi karena adanya inflamasi, meningkatnya katabolisme, kehilangan zat nutrisi melalui obat-obatan diuretik. (6)

Diagnosis gizi pada pasien ini ditegakkan berdasarkan SGA maka pasien dikategorikan dalam moderate malnutrition karena pada anamnesis didapatkan informasi riwayat penurunan asupan makan, riwayat penurunan berat badan, adanya nafsu makan yang menurun, dan peningkatan kebutuhan akibat penyakit yang diderita. Pada pemeriksaan fisis ditemukan adanya edema pada kedua dorsum pedis dan pretibial. Sedangkan pada laboratorium didapatkan albumin dan TLC yang rendah. (7)

Pada pasien diberikan komposisi karbohidrat pada awalnya 45\%, selanjutnya dinaikkan secara bertahap sampai 50\% sesuai kondisi klinis dan hasil pemeriksaan 
laboratorium pasien. Kadar gula darah yang tinggi akibat dari kompensasi resistensi insulin yang berkorelasi terhadap kadar trigliserida. (5) Selain itu riwayat pola makan pasien yang sering mengkonsumsi makanan dan minuman manis yang mengandung fruktosa, dimana fruktosa akan meningkatkan konsentrasi asam urat yang akan mempengaruhi disfungsi endotelial, sehingga produksi nitric oxide menurun. Hal ini akan mengganggu mediasi insulin yang pada akhirnya mengganggu pengambilan glukosa untuk sel sehingga berisiko terjadinya resistensi insulin. Kadar glukosa yang tinggi menyebabkan terjadinya glikosilasi protein membran basalis, sehingga terjadi penebalan selaput membran basalis, dan terjadi pula penumpukkan zat serupa glikoprotein membran basalis pada mesangium sehingga lambat laun kapilerkapiler glomerulus terdesak, dan aliran darah terganggu yang dapat menyebabkan glomerulosklerosis dan hipertrofi nefron yang akan menimbulkan nefropati diabetik. Nefropati diabetik menimbulkan berbagai perubahan pada pembuluh-pembuluh kapiler dan arteri, penebalan selaput endotelial, trombosis, adalah karakteristik dari mikroangiopati diabetik dan mulai timbul setelah periode satu atau dua tahun menderita Diabetes Melitus. Selain itu Adanya hidronefrosis akibat dari ureterolithiasis menyebabkan obstruksi pada ureter sehingga menyebabkan aliran merupakan salah satu faktor penyebab penurunan fungsi ginjal. (1), (4), (8), (9)

Pada pasien juga didapatkan penurunan fungsi ginjal yang ditandai dengan meningkatnya ureum dan kreatinin. Diberikan komposisi protein pada awalnya 0,8 $\mathrm{g} / \mathrm{kgBBI} / \mathrm{hari}$ dan dinaikkan secara bertahap sampai $1 \mathrm{~g} / \mathrm{kgBBI} / \mathrm{hari}$ sesuai kondisi pasien dan hasil ureum dan kreatinin yang semakin menunjukkan perbaikan. Peningkatan ureum merupakan salah faktor yang menstimulasi limfosit sehingga menyebabkan deplesi sistem imun. Selain itu faktor usia, dan reaksi anti inflamasi akibat dari kanker juga mempengaruhi menurunnya sistem imun. (1)

Beberapa bukti penelitian antara lain yang dilakukan oleh Molitch dkk (2015), Kalantar-Zadeh (2017), dan Nezu dkk (2013) yang menunjukkan bahwa terapi diet, terutama diet rendah protein adalah terapi yang aman dan dapat menekan perkembangan ND. (2)

Komposisi lemak yang diberikan pada awalnya adalah $41 \%$ dan meningkat secara bertahap sampai $47 \%$, oleh karena mengikuti komposisi dari karbohidrat dan protein. Dimana diberikan MUFA yaitu berupa extra virgin olive oil (EVOO). Extra virgin olive oil berpotensi sebagai sumber 
lemak dalam makanan, antioksidan dan antiinflamasi. Pemberian EVOO dikaitkan dengan insidens rendah dari risiko penyakit kardiovaskular. (10)

Adanya hipoalbuminemia yang terjadi pada pasien sehingga dinaikkan komposisi proteinnya menjadi 1 $\mathrm{g} / \mathrm{kgBBI} / \mathrm{hari}$ seiring dengan asupan makanan pasien yang menunjukkan toleransi terhadap komposisi makronutrien yang telah diberikan dan fungsi ginjal yang menunjukkan perbaikan. Hipoalbuminemia disebabkan adanya inflamasi yang sangat mempengaruhi sintesis albumin dan peningkatan katabolisme protein. Selain itu juga penurunan asupan protein karena pembatasan diet dan asupan makan yang menurun juga berkontribusi menurunkan kadar serum albumin. Pemberian protein yang adekuat ditambahkan dengan kapsul ekstrak ikan gabus, dengan tetap melakukan monitoring terhadap fungsi ginjal menunjukkan perbaikan albumin pada akhir perawatan. (11)

Diabetes mellitus dapat berkontribusi pada perkembangan penyakit jantung struktural dan gagal jantung melalui mekanisme sistemik, miokard, dan seluler. Telah ada bukti yang menunjukkan bahwa dishomeostasis mikronutrien dikaitkan dengan penyakit gagal jantung. Penelitian metaanalisis yang dilakukan oleh Xuefang
Yu dkk (2018) menemukan kadar serum zink secara signifikan lebih rendah pada pasien gagal jantung dibandingkan pada kelompok kontrol. (12) Pada pasien ini diberikan suplementasi zink $20 \mathrm{mg} / 24$ jam sebagai anti stres oksidatif dan sebagai suplementasi untuk defisiensi zink, dimana sitokin proinflamasi yang meningkat pada gagal jantung menginduksi metallothioneins sehingga kadar zink menjadi lebih rendah.(12) Menurut Yoshihisa dkk (2018), suplementasi zink bisa menjadi target terapi yang wajar pada pasien dengan gagal jantung. (13)

Adanya inflamasi pada pasien ini yang ditandai oleh leukositosis dan peningkatan ureum. Menurut Hewlings S dkk (2017), kurkumin mempunyai dua fungsi utama yaitu antiinflamasi dan antioksidan. Stres oksidatif memberikan dampak terhadap banyak penyakit kronik, dan proses patologisnya sangat berkaitan dengan inflamasi. Inflamasi telah diidentifikasi pada perkembangan dari banyak penyakit dan kondisi kronik yaitu penyakit kardiovaskular, kanker, diabetes mellitus.(14) Kurkumin menunjukkan efek penekanan terhadap inflamasi dengan menghambat aktivasi NF-kB yang meningkat akibat berbagai stimulus inflamasi. Oleh karena itu maka diberikan kurkumin $400 \mathrm{mg} / 8$ jam.(14) 
Pada pasien ini ditemukan anemia selama masa perawatan. Adanya karsinoma serviks mencetuskan pengeluaran sitokin proinflamasi terutama Interleukin-6 (IL-6) yang dilepaskan oleh tumor dan sel imun.

Selain itu adanya hiperglikemia kronis dapat menyebabkan sel darah merah abnormal, stres oksidatif dan denervasi ginjal. Semua faktor tersebut menyebabkan keadaan hipoksia di interstitium ginjal yang menyebabkan gangguan pada produksi eritropoietin oleh fibroblas peritubular. Eritropoietin merangsang sumsum tulang untuk membuat sel darah merah, sehingga jika terjadi gangguan dalam pembentukannya, hemoglobin tidak maksimal dibentuk dan terjadilah anemia. (15), (16). Oleh karena itu diberikan vitamin B kompleks pada pasien ini. Selain pemberian suplementasi vitamin B kompleks, pasien diedukasi untuk makan makanan yang mengandung vitamin B antara lain : gandum, sayuran berwarna hijau (selada, kubis, buncis), ikan, produk kedelai, susu, biji-bijian.(17) Oleh karena beberapa makanan tersebut juga dapat sebagai sumber karbohidrat, protein, lemak, dan zink, maka tentunya dengan tetap memperhatikan komposisi makronutrien dan mikronutrien yang telah ditetapkan sesuai dengan kondisi pasien.
Keterbatasan dari laporan kasus ini adalah kami tidak melakukan pemeriksaan penanda inflamasi sebagai kontrol keberhasilan pemberian anti inflamasi yang diberikan.

\section{Kesimpulan dan Saran}

Terapi nutrisi yang adekuat pada pasien dengan ND disertai gagal jantung dan karsinoma serviks dapat memperbaiki status gizi, status metabolik dan kualitas hidup pasien.

Diperlukan pemeriksaan penanda inflamasi untuk melihat keberhasilan terapi nutrisi dengan pemberian anti inflamasi yang diberikan dan penatalaksanaan yang komprehensif untuk mengoptimalkan luaran pasien yang baik.

\section{Daftar Pustaka}

1. Umanath $\mathrm{K}$, Lewis JB. Update on Diabetic Nephropathy: Core Curriculum 2018. Am J Kidney Dis [Internet]. 2018;71(6):884-95. Available from: https://doi.org/10.1053/j.ajkd.2017.10.026

2. Li Q, Wen F, Wang Y, Li S, Lin S, Qi C, et al. Diabetic Kidney Disease Benefits from Intensive Low-Protein Diet: Updated Systematic Review and Metaanalysis. Diabetes Ther [Internet]. 2020; Available from: https://doi.org/10.1007/s13300-02000952-5

3. Kemenkes RI. Hasil Utama Riskesdas 2018. 2018;

4. Sulaiman MK. Diabetic nephropathy: recent advances in pathophysiology and challenges in dietary management. Diabetol Metab Syndr [Internet]. 2019;15 .

Available

from: 
https://doi.org/10.1186/s13098-019-04034

5. Schofield JD, Liu Y, Rayaz PR. Diabetes Dyslipidemia. Diabetes Ther. 2016;7(2):203-19.

6. Dunlay SM, Givertz MM, Aguilar D, Allen LA, Chan M, Desai AS, et al. Type 2 Diabetes Mellitus and Heart Failure: A Scientific Statement From the American Heart Association and the Heart Failure Society of America: This statement does not represent an update of the 2017 ACC/AHA/HFSA heart failure guideline update. Vol. 140, Circulation. 2019. 294$324 \mathrm{p}$.

7. Kementerian Kesehatan RI. Pedoman Nasional Pelayanan Kedokteran Tata Laksana Malnutrisi pada Dewasa. 2019. 5-10 p.

8. Braunwald E. Diabetes, heart failure, and renal dysfunction: The vicious circles. Prog Cardiovasc Dis. 2019;62(4):298302.

9. Kurniawan LB, Aprianti S, Bahrun U, Pakasi RDN. Hipertrigliseridemia Sangat Berat pada Penderita Diabates Melitus Tipe 2. Cdk-207. 2013;40(8):600-2.

10. Jimenez-lopez C, Carpena M, Lourençolopes C, Gallardo-gomez M, Lorenzo JM, Barba FJ, et al. Bioactive Compounds and Quality of Extra Virgin Olive Oil. Review. 2020;1-31.

11. Kementerian Kesehatan RI. Pedoman Nasional Pelayanan Kedokteran Tata
Laksana Malnutrisi pada Dewasa. 2017.

12. Yu X, Huang L, Zhao J, Wang Z, Yao W, Wu X, et al. The Relationship between Serum Zinc Level and Heart Failure: A Meta-Analysis. Biomed Res Int. 2018;2018(June 2016).

13. Yoshihisa A, Abe S, Kiko T, Kimishima Y, Sato Y, Watanabe S, et al. Association of Serum Zinc Level With Prognosis in Patients With Heart Failure. J Card Fail [Internet]. 2018;24(6):375-83. Available from:

https://doi.org/10.1016/j.cardfail.2018.02. 011

14. Hewlings S, Kalman D. Curcumin: A Review of Its' Effects on Human Health. Foods. 2017;6(10):92.

15. Singh DK, Winocour P, Farrington K. reviews Erythropoietic stress and anemia in diabetes mellitus. 2009;5(April).

16. Madeddu C, Gramignano G, Astara G, Demontis R, Sanna E, Atzeni V, et al. Pathogenesis and Treatment Options of Cancer Related Anemia : Perspective for a Targeted Mechanism-Based Approach. 2018;9(September):1-20.

17. Cappuccilli M, Bergamini C, Giacomelli FA, Cianciolo G, Donati G, Conte D, et al. Vitamin B supplementation and nutritional intake of methyl donors in patients with chronic kidney disease: A critical review of the impact on epigenetic machinery. Nutrients. 2020;12(5):1-20. 


\section{Grafik Monitoring asupan energi via oral dan parenteral}



\section{Grafik Monitoring asupan karbohidrat via oral}






\section{Grafik Monitoring asupan protein via oral dan parenteral}



Grafik Monitoring asupan lemak via oral dan parenteral

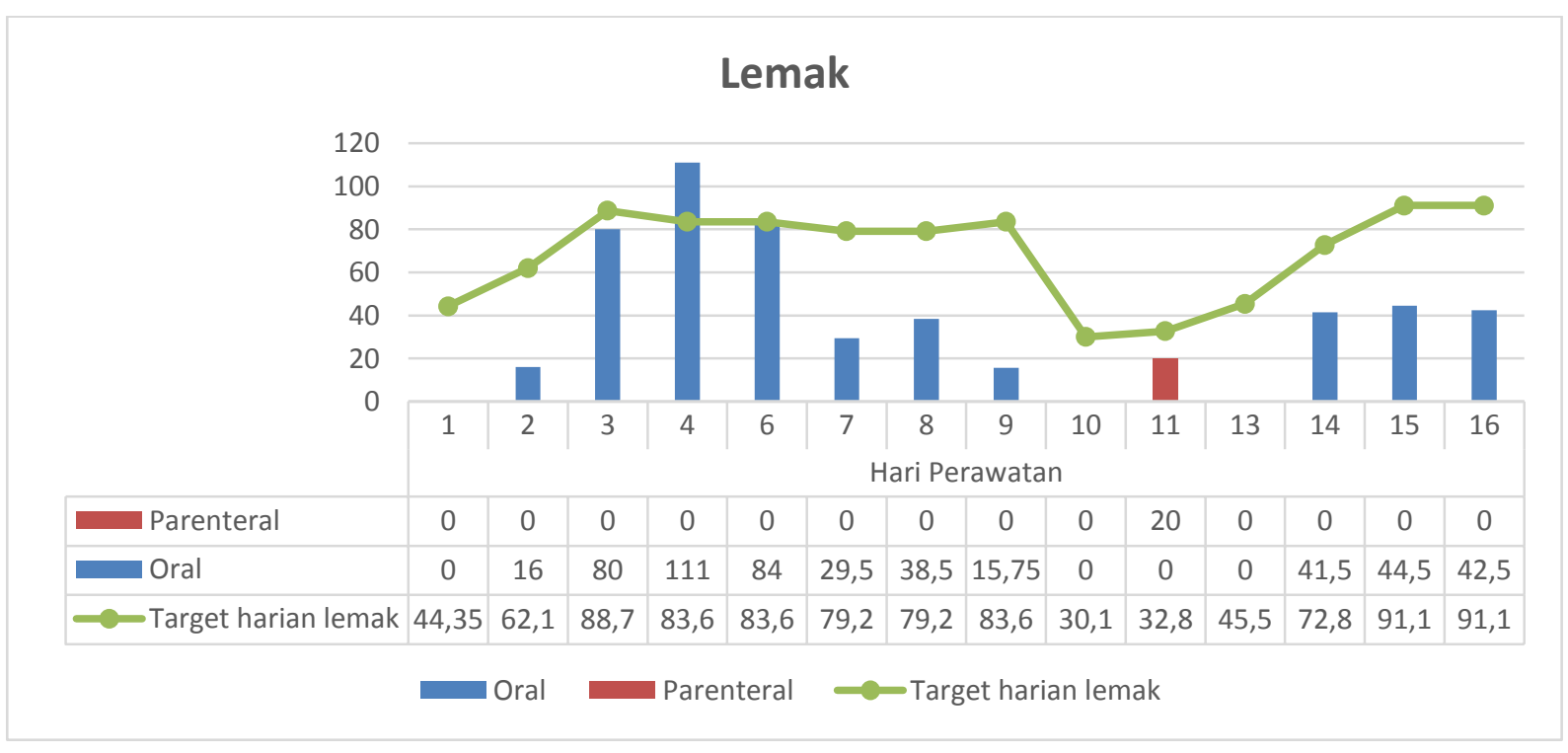




\section{Grafik Perkembangan Klinis Pasien}

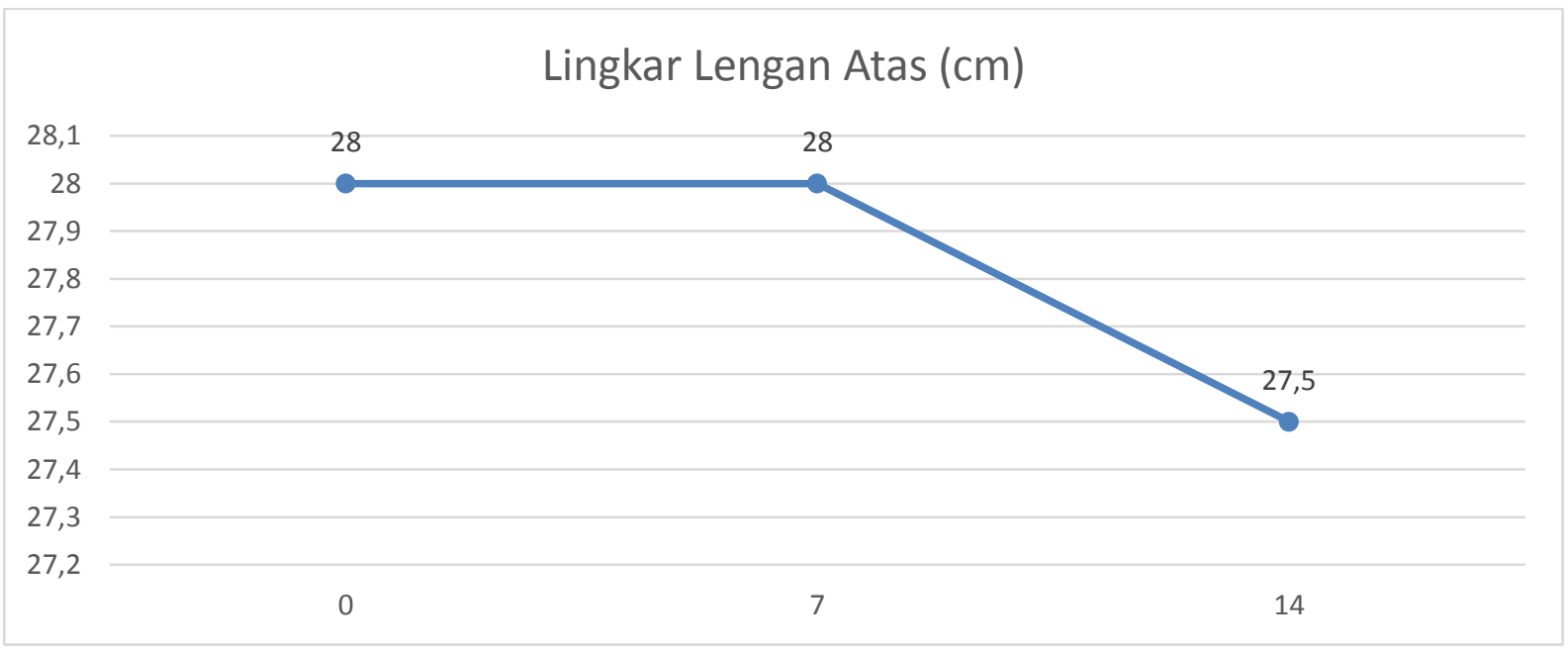

Tabel Monitoring Pemeriksaan Laboratorium Selama Masa Perawatan

\begin{tabular}{|c|c|c|c|c|c|c|c|c|c|c|c|c|c|c|c|}
\hline \multicolumn{15}{|c|}{ Jenis Pemeriksaan } & \multirow{2}{*}{ Nilai Normal } \\
\hline & $1 / 2 / 19$ & $3 / 2 / 19$ & $4 / 2 / 19$ & $5 / 2 / 19$ & $6 / 2 / 19$ & $7 / 2 / 19$ & $8 / 2 / 19$ & $11 / 2 / 19$ & $13 / 2 / 19$ & $14 / 2 / 19$ & $15 / 2 / 19$ & $18 / 2 / 19$ & $23 / 2 / 19$ & $25 / 2 / 19$ & \\
\hline WBC & 14000 & 18700 & & 10800 & & 10400 & 16000 & & 11600 & & 7200 & & 9200 & 7600 & $4-10 \times 103 / \mathrm{ml}$ \\
\hline $\mathrm{HB}$ & 6,7 & 12,7 & & 9,9 & & 8,3 & 8,2 & & 6,8 & & 10 & & 10,3 & 8,2 & $12-16 \mathrm{~g} / \mathrm{dl}$ \\
\hline $\mathrm{MCV}$ & 82 & 79 & & 76 & & 86 & 75 & & 75 & & 77 & & 77 & 77 & $80-100 \mathrm{nM} 3$ \\
\hline $\mathrm{MCH}$ & 26 & 26 & & 26 & & 26 & 26 & & 26 & & 27 & & 27 & 27 & $27-32 \mathrm{pg}$ \\
\hline $\mathrm{MCHC}$ & 32 & 33 & & 34 & & 30 & 34 & & 34 & & 35 & & 35 & 35 & $32-36 \mathrm{pg}$ \\
\hline PLT & 130000 & 12000 & & 12000 & & 22000 & 65000 & & 165000 & & 265000 & & 238000 & 223000 & $150-400 \times 103 / \mathrm{mm} 3$ \\
\hline TLC & 924 & 1178 & & 734,4 & & 1903 & 784 & & 487,2 & & 842 & & 487,6 & 554,8 & $2-4 \times 103 / \mathrm{ml}$ \\
\hline GDS & & & 398 & & & & & & & & & & & & $140-200 \mathrm{mg} / \mathrm{dl}$ \\
\hline SGOT & 29 & & & & & & & & & & & & 141 & & $\mathrm{P}<32 \mathrm{U} / \mathrm{L}, \mathrm{L}<38 \mathrm{U} / \mathrm{L}$ \\
\hline SGPT & 15 & & & & & & & & & & & & 51 & & $\mathrm{P}<31 \mathrm{U} / \mathrm{L}, \mathrm{L}<41 \mathrm{U} / \mathrm{L}$ \\
\hline Protein total & & & & & 5,2 & & & 5,2 & 5,5 & & & & & 6,3 & $6.6-8.7 \mathrm{~g} / \mathrm{dL}$ \\
\hline Albumin & 2,8 & 2,3 & & & 2,5 & 2,1 & 2,6 & 2,4 & 2,6 & & 3 & & & 2,8 & $3.5-5.0 \mathrm{~g} / \mathrm{dL}$ \\
\hline Ureum & 144 & 119 & 144 & & & 129 & 137 & 100 & 98 & & 112 & 106 & 84 & & $10-50 \mathrm{mg} / \mathrm{dL}$ \\
\hline \multirow{2}{*}{ Kreatinin } & \multirow{2}{*}{3,2} & \multirow{2}{*}{2,83} & \multirow{2}{*}{3,2} & & & \multirow{2}{*}{2,76} & \multirow{2}{*}{2,4} & \multirow{2}{*}{1,91} & \multirow{2}{*}{2,05} & & \multirow{2}{*}{2,39} & \multirow{2}{*}{2,27} & \multirow{2}{*}{2,05} & & $\mathrm{~L}<1.3 \mathrm{mg} / \mathrm{dL}$ \\
\hline & & & & & & & & & & & & & & & $\mathrm{P}<1,1 \mathrm{mg} / \mathrm{dL}$ \\
\hline Kreatinin Klerens & & & & & & & & 42,53 & & & & & & & 74-112 m/menit \\
\hline $\mathrm{Na}$ & 128 & 125 & & & 129 & 126 & 123 & 120 & 120 & & 131 & & 126 & & $136-145 \mathrm{mmol} / \mathrm{L}$ \\
\hline $\mathrm{K}$ & 4,3 & 4,9 & & & 4,1 & 4,4 & 4,1 & 4,1 & 4,3 & & 4,4 & & 4,4 & & $3,5-5,1 \mathrm{mmol} / \mathrm{L}$ \\
\hline $\mathrm{Cl}$ & 103 & 105 & & & 105 & 107 & 99 & 94 & 93 & & 102 & & 96 & & $97-111 \mathrm{mmol} / \mathrm{L}$ \\
\hline PT & & & & & & & & & & 11,4 & & & & & $10-14$ \\
\hline INR & & & & & & & & & & 1,1 & & & & & - \\
\hline APTT & & & & & & & & & & 27,6 & & & & & $22-30$ \\
\hline Kolesterol & & & & & 135 & & & & & & & & & & $<200 \mathrm{mg} / \mathrm{dL}$ \\
\hline \multirow{2}{*}{ HDL } & & & & & \multirow{2}{*}{4} & & & & & & & & & & $\mathrm{~L}>55 \mathrm{mg} / \mathrm{dL}$ \\
\hline & & & & & & & & & & & & & & & $\mathrm{P}>65 \mathrm{mg} / \mathrm{dL}$ \\
\hline LDL & & & & & 4 & & & & & & & & & & $<130 \mathrm{mg} / \mathrm{dL}$ \\
\hline Trigliserida & & & & & 640 & & & & & & & & & & $<200 \mathrm{mg} / \mathrm{dL}$ \\
\hline \multirow{2}{*}{ Asam urat } & & & & & \multirow{2}{*}{13,1} & & & & & & & & & \multirow{2}{*}{7,3} & $\mathrm{P}(2,4-5,7 \mathrm{mg} / \mathrm{dL})$ \\
\hline & & & & & & & & & & & & & & & $\mathrm{L}(3,4-7,0 \mathrm{mg} / \mathrm{dL})$ \\
\hline
\end{tabular}

